\title{
Role of Kisspeptin and Neurokinin $B$ in Puberty in Female Non-Human Primates
}

\author{
Ei Terasawa ${ }^{1,2 *}$, James P. Garcia ${ }^{1}$, Stephanie B. Seminara ${ }^{3}$ and Kim L. Keen ${ }^{1}$ \\ ${ }^{1}$ Wisconsin National Primate Research Center, University of Wisconsin, Madison, WI, United States, ${ }^{2}$ Department \\ of Pediatrics, University of Wisconsin, Madison, WI, United States, ${ }^{3}$ Reproductive Endocrine Unit and the Harvard \\ Reproductive Sciences Center, Department of Medicine, Massachusetts General Hospital, Boston, MA, United States
}

\section{OPEN ACCESS}

Edited by:

William Henry Colledge, University of Cambridge,

United Kingdom

Reviewed by:

Víctor M. Navarro,

Harvard Medical School,

United States

Tony Plant,

University of Pittsburgh,

United States

${ }^{*}$ Correspondence:

Ei Terasawa

terasawa@primate.wisc.edu

Specialty section:

This article was submitted to

Neuroendocrine Science,

a section of the journal

Frontiers in Endocrinology

Received: 07 December 2017

Accepted: 20 March 2018

Published: 06 April 2018

Citation:

Terasawa E, Garcia JP, Seminara SB and Keen KL (2018) Role of

Kisspeptin and Neurokinin

$B$ in Puberty in Female Non-Human

Primates.

Front. Endocrinol. 9:148.

doi: 10.3389/fendo.2018.00148
In human patients, loss-of-function mutations in the genes encoding kisspeptin (KISS1) and neurokinin $\mathrm{B}(N K B)$ and their receptors (KISS1R and NK3R, respectively) result in an abnormal timing of puberty or the absence of puberty. To understand the neuroendocrine mechanism of puberty, we investigated the contribution of kisspeptin and NKB signaling to the pubertal increase in $\mathrm{GnRH}$ release using rhesus monkeys as a model. Direct measurements of $\mathrm{GnRH}$ and kisspeptin in the median eminence of the hypothalamus with infusion of agonists and antagonists for kisspeptin and NKB reveal that kisspeptin and NKB signaling stimulate $\mathrm{GnRH}$ release independently or collaboratively by forming kisspeptin and NKB neuronal networks depending on the developmental age. For example, while in prepubertal females, kisspeptin and NKB signaling independently stimulate $\mathrm{GnRH}$ release, in pubertal females, the formation of a collaborative kisspeptin and NKB network further accelerates the pubertal increase in $\mathrm{GnRH}$ release. It is speculated that the collaborative mechanism between kisspeptin and NKB signaling to $\mathrm{GnRH}$ neurons is necessary for the complex reproductive function in females.

Keywords: kisspeptin, neurokinin B, GnRH, puberty, nonhuman primate

\section{INTRODUCTION}

Puberty is a transitional period between the sexually immature juvenile stage and adulthood, after which full reproductive function is attained. In the 1980s, the concept that an increase in GnRH release initiates puberty was established. Although from 1980 to 2000, it became clear that central inhibition over $\mathrm{GnRH}$ release during the prepubertal period needs to be removed or diminished in primates (1), the discovery that gene mutations in kisspeptin (KISS1) and its receptor (KISS1R) in human patients result in delayed puberty or no puberty $(2,3)$ has generated great progress in understanding the mechanism of puberty. Together, with the subsequent findings showing that mutations in neurokinin $\mathrm{B}(\mathrm{NKB})$ and its receptor $(N K 3 R)$ in humans also result in delayed puberty or no puberty (4), this led us to study how kisspeptin and NKB signaling changes before and after puberty onset in female rhesus monkeys. This short review article summarizes our findings and perspectives regarding the role of kisspeptin and NKB signaling in puberty onset in females.

\section{DEVELOPMENTAL CHANGES IN GONADOTROPIN SECRETION IN FEMALE RHESUS MONKEYS}

Based on developmental changes in LH and FSH levels and external signs of puberty, we have defined the pubertal stages as follows: The "prepubertal stage" is when female monkeys do not exhibit any external signs of puberty and gonadotropin levels are low, generally before 20 months of age. 
Prepubertal monkeys exhibit a low frequency and amplitude of LH pulses and there is little nocturnal increase in LH (5). The "early pubertal stage" is defined as the time between the appearance of the first external signs of puberty and menarche. The first external signs of female puberty, such as a slight increase in the nipple size and subsequent swelling of perineal sex-skin, usually occur at 20-25 months of age. These external signs of puberty are a consequence of increased levels of circulating gonadotropins and ovarian estrogens: The LH pulse amplitude starts to increase and a nocturnal elevation of gonadotropin levels becomes prominent (5). Subsequently, menarche occurs at 26-30 months of age. After menarche, females have irregular menstrual cycles without ovulation. Mean LH levels, LH pulse amplitude (not pulse frequency), and nocturnal LH further increase and at 36-45 months of age, monkeys start to ovulate. We have defined this developmental stage between menarche and first ovulation as the "midpubertal stage" [Figure 1; (5)].

\section{RELEASE OF GnRH AND KISSPEPTIN INCREASES AT PUBERTY}

\section{GnRH Release}

An increase in $\mathrm{GnRH}$ is a prerequisite for the initiation of puberty. This concept is based on an experiment showing that pulsatile infusion of $\mathrm{GnRH}$ in sexually immature female monkeys by infusion pump resulted in precocious puberty (6) and that an increase in $\mathrm{GnRH}$ release occurs at puberty onset in female rhesus monkeys (7). In the prepubertal female, $\mathrm{GnRH}$ release is pulsatile and characterized by low mean levels, low pulse frequency, low amplitude, and no nocturnal increases (7). In early pubertal females, mean GnRH levels, pulse frequency, and pulse amplitude are all increased, and nocturnal increases in GnRH release start to appear $(7,8)$. In midpubertal females, mean GnRH levels and pulse-amplitude, but not pulse frequency, further increase reaching the highest levels (7). Additionally, nocturnal GnRH increases become most prominent $(7,8)$. A similar pubertal increase in pulsatle GnRH release in rodents and sheep (9-11) has been shown by direct measurements, and in humans by indirect LH measurements (12-14). Because the pubertal increase in $\mathrm{GnRH}$ release is ovarian steroid independent (1), ovariectomized (OVX) females at the prepubertal stage exhibit a low mean, low pulse frequency, and low pulse amplitude GnRH release, similar to those in gonadally intact counterparts. In OVX females, at the early and midpubertal stages, mean GnRH levels and GnRH pulse amplitude are much higher than in ovarian intact females, but the pulse frequency stays similar, at $\sim 1$ pulse/h (8). A similar pubertal change in LH release in human gonadal dysgenesis patients with Turner's syndrome has also been reported $(14,15)$.

\section{Kisspeptin Release}

As we described for GnRH release, kisspeptin is released in the median eminence in a pulsatile manner (16). Additionally, kisspeptin release in females undergoes pubertal changes, parallel to those with $\mathrm{GnRH}$ release. The mean release, pulse frequency, and pulse amplitude of kisspeptin release in pubertal female monkeys are all higher than those in prepubertal females (17). Again, examination of the effects of OVX on kisspeptin release indicates that while OVX stimulates kisspeptin release in pubertal females, it does not change in prepubertal females (17). That is, kisspepetin release in prepubertal OVX females is characterized with low mean release, low pulse frequency, and low amplitude similar to those in ovarian intact prepubertal females, whereas kisspeptin release in pubertal OVX females consists of higher mean release and higher pulse amplitude, but not higher pulse frequency, when compared to ovarian intact pubertal females (17). Therefore, the pubertal increase in kisspeptin release in primates is ovarian steroid independent. Importantly, however, similar to GnRH release (18), treatment with estradiol suppresses elevated kisspeptin levels in pubertal females, whereas estradiol does not change kisspeptin levels in prepubertal females (17).

In humans, elevated levels of circulating kisspeptin in association with precocious puberty or premature thelarche have been reported (19-23). This is consistent with our results derived from direct kisspeptin measurements in the hypothalamus. Nevertheless, the validity of the finding in human studies is unclear, as circulating kisspeptin may not be of hypothalamic origin. In mammalian species, kisspeptin is synthesized not only in the various part of the brain (24) and placenta but also in peripheral tissues such as the adrenals, ovaries, testes, and kidney (25-28).

\section{GnRH RESPONSE TO THE KISSPEPTIN RECEPTOR AGONIST, KISSPEPTIN-10, INCREASES AT PUBERTY}

Since its discovery, kisspeptin has been identified as the most powerful secretagoue for GnRH release (29). GnRH neurons express kisspeptin receptors (Kiss1r) (30, 31), kisspeptin-10

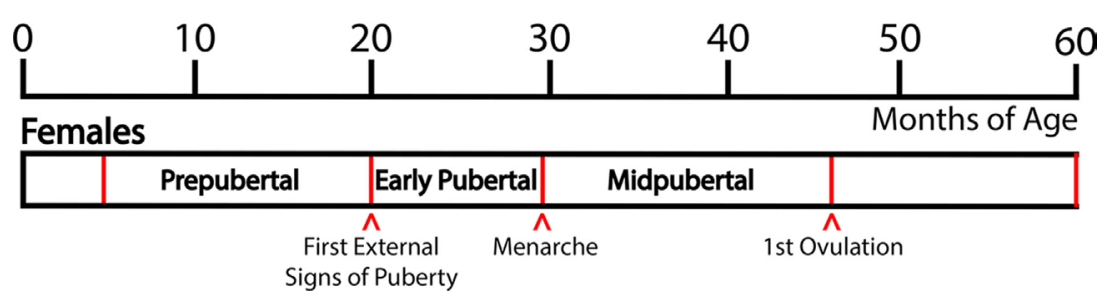

FIGURE 1 | Developmental stages of pubertal progression in female rhesus monkeys. Based on changes in physiological characteristics and in circulating hormone levels during the developmental course, prepubertal, early pubertal, and midpubertal stages are defined as shown in this figure. Actual age of the onset of puberty and subsequent progress vary among animals. 
(hKP10) directly depolarizes GnRH neurons and sensitivity of $\mathrm{GnRH}$ response to kisspeptin undergoes pubertal changes in rodents (30). In humans and monkeys, contacts between $\mathrm{GnRH}$ and kisspeptin neuroterminals in the median eminence, which is indicative of a non-synaptic signaling mechanism, have been reported $(32,33)$.

To clarify the role of kisspeptin signaling in the pubertal increase in GnRH in female monkeys, we first assessed the manner in which the GnRH response to hKP10 changes throughout puberty. GnRH neurons in gonadally intact prepubertal and pubertal females respond to human hKP10 at 0.01 and $0.1 \mu \mathrm{M}$ doses in a dose-responsive manner (34). Importantly, the $\mathrm{GnRH}$ response to hKP10 at the same dose in pubertal females is larger than that in prepubertal females [Figure 2; (34)]. This indicates that GnRH neurons in pubertal monkeys are more sensitive than in prepubertal monkeys.

Because circulating gonadal steroid levels between prepubertal and pubertal animals differ, higher sensitivity of GnRH neurons to kisspeptin signaling in pubertal females may be due to circulating steroids, namely estradiol. Accordingly, we examined the effect of OVX on the developmental changes in $\mathrm{GnRH}$ responses to hKP10 in female monkeys (34). While OVX in prepubertal animals does not alter GnRH response to hKP10, OVX completely abolished the hKP10-induced GnRH release in OVX pubertal females. Importantly, estradiol replacement in OVX pubertal females only partially restores the hKP10-induced GnRH release, suggesting that circulating estradiol is important for kisspeptin action on GnRH neurons in pubertal females (34). One can argue that the absence of GnRH response to hKP10 in OVX monkeys is due to the limitation of the maximized kisspeptin neurosecretory capacity after OVX. We believe this is not the case, because (1) two doses (10 and $100 \mathrm{nM}$ ) of hKP10 failed to stimulate GnRH release in pubertal OVX females, whereas in prepubertal females, the lower dose $(10 \mathrm{nM})$ is sufficient to stimulate $\mathrm{GnRH}$ release (34), and (2) hKP10 (10 nM) can stimulate GnRH release in OVX pubertal females after priming with estradiol (34), although
GnRH release in estradiol primed OVX pubertal females was much smaller than that in ovarian intact pubertal females (34). Therefore, it is likely that once KISS1R is exposed to estradiol after the onset of puberty, the properties of KISS1R are altered, such that normal KISS1R function requires the presence of circulating estradiol or, at least, a periodical exposure to estradiol. This speculation, however, needs to be experimentally confirmed by examining whether changes in the KISS1R properties occur in the presence or absence of estradiol and how developmental factors are involved in the mechanism of the estrogen-induced KISS1R property change.

Collectively, we can interpret our findings to mean that the contribution of kisspeptin signaling to the pubertal increase in $\mathrm{GnRH}$ release in female monkeys is twofold: first, after puberty onset, a larger amount of kisspeptin is available to stimulate $\mathrm{GnRH}$ release, and second, sensitivity of KISS1R on GnRH neurons is higher because of the pubertal increase in circulating estradiol.

\section{GnRH RESPONSE TO THE NKB AGONIST, SENKTIDE, DOES NOT UNDERGO PUBERTAL CHANGE}

Neurokinin B action is primarily mediated by NK3R encoded by the TACR3 gene. Whether GnRH neurons express NK3R is somewhat controversial. While direct application of the NK3R agonist senktide on sliced brain preparation stimulates $\mathrm{GnRH}$ neuronal activity in mice (36) and the NK3R is described in close proximity to GnRH neuroterminals in rats and sheep $(37,38)$, only a small number or no GnRH neuronal cell bodies express NK3R in rat and mice $(37,39,40)$. In mice and sheep, however, kisspeptin, $\mathrm{NKB}$, and dynorphin (KNDy) neurons expressing NK3R in the arcuate nucleus (ARC) appear to mediate NKB action to GnRH neurons (39-41). Importantly, however, NKB neurons can signal to $\mathrm{GnRH}$ neurons directly at the median eminence, as similar to GnRH fibers, abundant NKB fibers project into the median
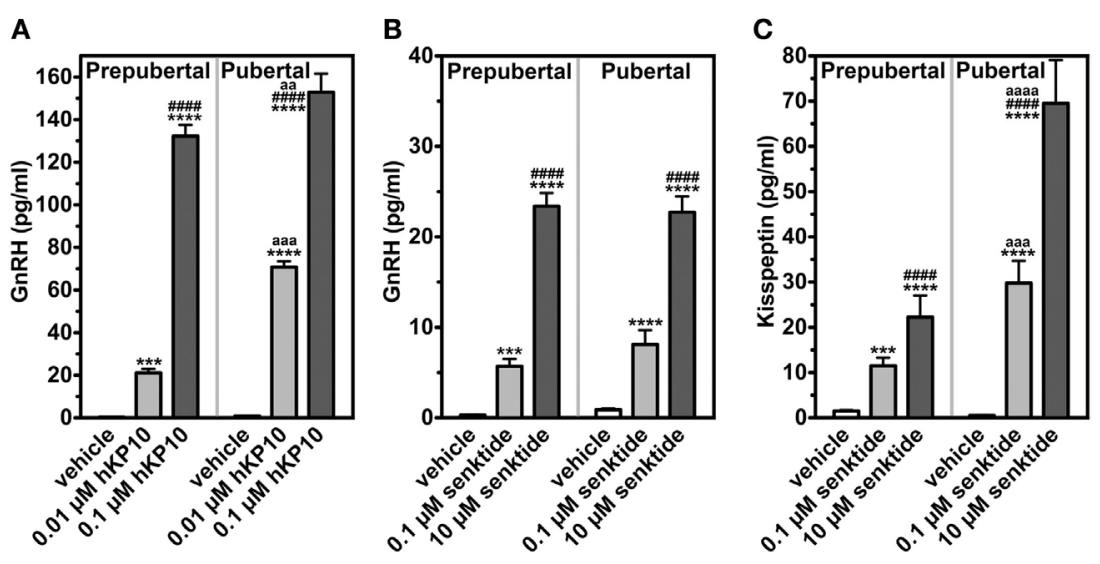

FIGURE 2 | Changes in release of GnRH and kisspeptin (area under the curve in response to challenge of secretagogues). GnRH in response to human kisspeptin-10 (hKP10) (A) and senktide (B) in female rhesus monkeys are shown. Kisspeptin response to senktide (C) is also shown. ${ }^{* \star *} p<0.001 ;{ }^{\star \star * \star} p<0.0001$

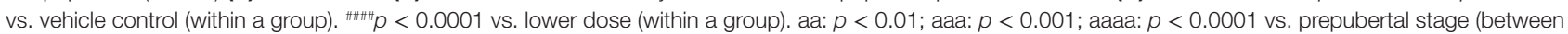
groups at the same dose of challenge). Modified from Ref. (35) with data from Ref. (34) with Copyright Permission. 
eminence and GnRH neuroterminal fibers readily express NK3R in the median eminence of rats and humans $(33,37,42,43)$.

We examined the effects of the NKB agonist, senktide, on GnRH release in gonadally intact prepubertal and pubertal female monkeys. Senktide infusion into the median eminence at 0.1 and $10 \mu \mathrm{M}$ stimulated $\mathrm{GnRH}$ release in a dose responsive manner within the same developmental stage [(35); Figure 2]. However, neither 0.1 nor $10 \mu \mathrm{M}$ senktide results in developmental amplification. The results indicate that the NKB system appears not to be sensitive to the pubertal increases in steroid hormones. We have not conducted the parallel experiments in OVX monkeys.

Stimulatory effects of senktide on GnRH release in our study are consistent with those reported in juvenile orchidectomized male rhesus monkeys assessed by LH measurement (44). However, in rodents, both stimulatory and inhibitory effects of $\mathrm{NKB}$ on LH/GnRH release (depending on sex, gonadal status, and ages) have been reported $(39,40,45-47)$.

\section{KISSPEPTIN RESPONSE TO THE NKB AGONIST, SENKTIDE, UNDERGOES PUBERTAL CHANGE}

Kisspeptin, NKB, and dynorphin (KNDy) are 100\% co-localized in the ARC and express estrogen receptor alpha in sheep. Based on the anatomical characteristics along with the self-regulating stimulatory and inhibitory circuitry between NKB, kisspeptin, and dynorphin, Goodman and co-workers $(48,49)$ have proposed the hypothesis that KNDy neurons in the ARC are responsible for GnRH pulse-generation (50). Subsequently, this concept, including the $100 \%$ colocalization rate of three peptides in the ARC, and KNDy neurons as a driver of GnRH pulse-generation, has been confirmed in several species, including rats, mice, and goats (51-54). Nevertheless, we have hypothesized that kisspeptin, $\mathrm{NKB}$, and dynorphin neurons in the hypothalamus of monkeys form a network as each independent unit. This hypothesis is based on the reports that (1) in the human hypothalamus the co-localization rate of kisspeptin, $\mathrm{NKB}$, and dynorphin in the infundibular nucleus (aka ARC) is considerably lower than in other species $(33,55),(2)$ co-localization of kisspeptin and NKB fibers in the median eminence in humans is relatively rare (33) although this is not the case in male monkeys (56), and (3) unlike in rodents $(57,58)$, perikarya of kisspeptin neurons in monkeys and human and perikarya of NKB neurons in humans are seen in the median eminence $(32,33)$.

As the first step to test this hypothesis, we measured kisspeptin in the same samples collected from the median eminence, in which the effects of senktide on $\mathrm{GnRH}$ release were examined. The effects of senktide on kisspeptin release in females are strikingly parallel to its effects on GnRH (35). Kisspeptin responses to senktide at 0.1 and $10 \mu \mathrm{M}$ in females are dose dependent within the developmental stage. However, senktide at both 0.1 and $10 \mu \mathrm{M}$ doses yield an approximately twofold developmental amplification of kisspeptin release in females [(35); Figure 2]. We speculate that circulating estradiol is responsible for the developmental amplification of senktide-induced kisspeptin release, as the female kisspeptin system is highly sensitive to estradiol.
The important question here is why a larger release of kisspeptin induced by senktide in pubertal females than prepubertal females is not directly transduced to a larger $\mathrm{GnRH}$ release? We speculate that this is due to involvement of opioid input, as opioid tone increases after puberty onset. In fact, it has been shown that opioid tone increases along with the pubertal increase in estradiol/testosterone. For example, while administration of antagonists for opioid peptides, such as naloxone and naltrexone, in prepubertal children, chimpanzees, and rhesus monkeys failed to stimulate $\mathrm{LH} / \mathrm{GnRH}$ release (59-64), these opioid antagonists consistently suppress pulsatile LH release in sexually mature humans and monkeys (65-68). Moreover, proopiomelanocortin mRNA expression increases along with progress of puberty in male monkeys (69) and $\beta$-endorphin release in the median eminence increases in association with puberty onset in female monkeys (70). A similar view has been reported in ewe (71). Perhaps, the pubertal increase in stimulatory kisspeptin and NKB signaling tones is counterbalanced by opioid peptides. Additional investigations are needed to confirm this view.

\section{DEVELOPMENTAL CHANGES IN THE NEUROCIRCUITS INVOLVED IN THE PUBERTAL INCREASE IN GnRH RELEASE}

As described above, both hKP10 and senktide stimulate GnRH release in a dose-responsive manner in prepubertal as well as pubertal female monkeys $(34,35)$. We also described that senktide greatly stimulates kisspeptin release in a dose-dependent manner in both prepubertal and pubertal females (35). However, these observations in females do not suggest any hierarchical relationship between $\mathrm{NKB}$ and kisspeptin signaling. Moreover, the network between kisspeptin and NKB signaling may undergo pubertal changes. Therefore, in the next series of studies, we have examined whether NKB signaling is mediated through kisspeptin neurons or kisspeptin signaling is mediated through $\mathrm{NKB}$ neurons using respective agonists and antagonists. The results indicate that the senktide-induced $\mathrm{GnRH}$ release is blocked in the presence of the KISS1R antagonist, peptide 234, in pubertal, but not prepubertal monkeys (35). Similarly, hKP10-induced GnRH release is blocked by the NK3R antagonist SB222200 in pubertal, but not prepubertal monkeys (35). These results suggest that while in prepubertal female monkeys, kisspeptin and $\mathrm{NKB}$ signaling influences $\mathrm{GnRH}$ release as independent units, in pubertal female monkeys, a reciprocal signaling network (i.e., NKB signaling through kisspeptin neurons and kisspeptin signaling through NKB neurons) is established (Figure 3). This cooperative mechanism by the kisspeptin and NKB networks appears to underlie the pubertal increase in $\mathrm{GnRH}$ release in female monkeys. We speculate that the cooperative mechanism between kisspeptin and NKB signaling to GnRH release would ensure the success of complex reproductive functions in females.

Our findings reported in this manuscript are obtained from dialysates collected from the median eminence, where agonists and antagonists for kisspeptin and NKB are directly infused. Because of our technical precision (72), interactions between $\mathrm{GnRH}$ and kisspeptin neurons, kisspeptin and NKB neurons, and 
GnRH and NKB neurons are likely taking place at the median eminence and infundibular stalk (extended median eminence). As we discussed above, the primate median eminence appears to be equipped for this purpose. In the median eminence neuroterminal interactions between NKB, kissepeptin, and GnRH neurons are likely to occur through a non-synaptic mechanism, but the presence of kisspeptin, NKB, and GnRH neuronal cell bodies in the median eminence $(32,33,73,74)$ indicates possible synaptic interactions as well. Nevertheless, currently, we do not know the degree to which the median eminence kisspeptin-NKB system is influenced by the infundibular (ARC) kisspeptin-NKB system. It will be a major task to clarify the mechanisms of developmental changes in these signaling pathways that regulate $\mathrm{GnRH}$ release.

\section{PULSATILITY OF GNRH RELEASE AND TIMING OF PUBERTY}

Genetic findings in humans indicate that both kisspeptin and $\mathrm{NKB}$ signaling is critical for the mechanism governing puberty onset (2-4). Similar findings in kisspeptin and NKB knockout mice were also reported $(75,76)$. As we discussed above, kisspeptin signaling itself $(77,78)$ or the KNDy network (50) is indispensable for pulsatility of $\mathrm{GnRH}$ release and an increase in pulsatile GnRH release is required for puberty onset (1). Here, a critical question arises as to whether kisspeptin and NKB signaling determines the timing of puberty in primates. In other words, does an increased activity of kisspeptin signaling/KNDy network during development facilitate pulsatile $\mathrm{GnRH}$ release initiating puberty onset $\mathrm{OR}$ is an increased activity of kisspeptin signaling/KNDy network a consequence of reduction in "Central Inhibition"? The following is our view.

In primates, GnRH neurons in the hypothalamus are already active at birth and elevated GnRH neuronal activity induces a socalled "mini-puberty" during the neonatal period (79). However, activity of the GnRH neurosecretory system is suppressed by "Central Inhibition" and becomes dormant throughout the prepubertal period (80). Neuronal substrates that represent "Central Inhibition" are currently unclear. Our previous studies indicate that tonic inhibition by $\gamma$-aminobutyric acid (GABA) neurons may be one component $(1,81)$ and neuroestradiol $(72)$ might be another component. It has also been postulated that MKRN3 protein may be responsible for suppression of GnRH release before puberty, as mutations of the makorin RING finger protein 3 gene $(M K R N 3)$ result in precocious puberty in humans (82). More recently, based on the gene array comparison between castrated prepubertal and pubertal male monkey hypothalami, followed by physiological experiments, the transcriptional repressor protein, GATAD1, is postulated as a substrate responsible for prepubertal GnRH suppression (83). Nevertheless, the report that the kisspeptin antagonist, peptide 234, blocks the $\mathrm{GABA}_{\mathrm{A}}$ antagonist bicuculline-induced GnRH increase in prepubertal females (84) suggests that "Central Inhibition" by GABA is upstream of the kisspeptin signaling system. We speculate that GABA is also upstream of NKB signaling and the NKB antagonist SB222200 would block the $\mathrm{GABA}_{\mathrm{A}}$ antagonist bicuculline-induced $\mathrm{GnRH}$ increase in prepubertal females. Therefore, removal or reduction in "Central Inhibition" is a prerequisite for allowing the pubertal increase in activity of kisspeptin neurons or the KNDy network (Figure 3). Once kisspeptin/KNDy neurons become active, kisspeptin and NKB signaling ensures the pulsatile GnRH release, resulting in the onset of puberty.

The concept of "Central Inhibition" is well documented in humans (85) and rhesus monkeys $(1,86)$, but it remains controversial in non-primate species. In fact, there are several species differences in the mechanism of puberty onset: (1) As described above, while neonatal castration in primates induces elevated LH/FSH release only transiently (87), the same procedure in rats and sheep results in a sustained increase in gonadotropin release throughout life (11, 88); (2) while the GnRH neuroscretory system in prepubertal monkeys is insensitive to estradiol and sensitivity to estradiol negative feedback is acquired during the early pubertal stage (18), the GnRH neurosecretory system in rodents is highly sensitive to estradiol action during the entire juvenile period and sensitivity to estradiol decreases after first ovulation (88); and (3) while precocious puberty induced by infusion of pulsatile GnRH or $N$-methyl-D-aspartic acid (NMDA) in prepubertal monkeys is halted by the cessation of the infusion $(6,89)$, precocious puberty induced in rodents with a similar treatment, such as NMDA administration, leads to the maintenance of adult gonadal function after discontinuation of treatment, i.e., NMDA-induced precocious puberty in rats is followed by cyclic ovulation (90).

Despite these species differences, however, in rodents, there are some parallel findings consistent with the concept of the "Central Inhibition" described in primates. For example, in mice, Mkrn3 mRNA expression in the ARC is highest during the first 10-12 postnatal days $(\mathrm{P})$, starts to decrease at $\mathrm{P} 15$, and becomes the

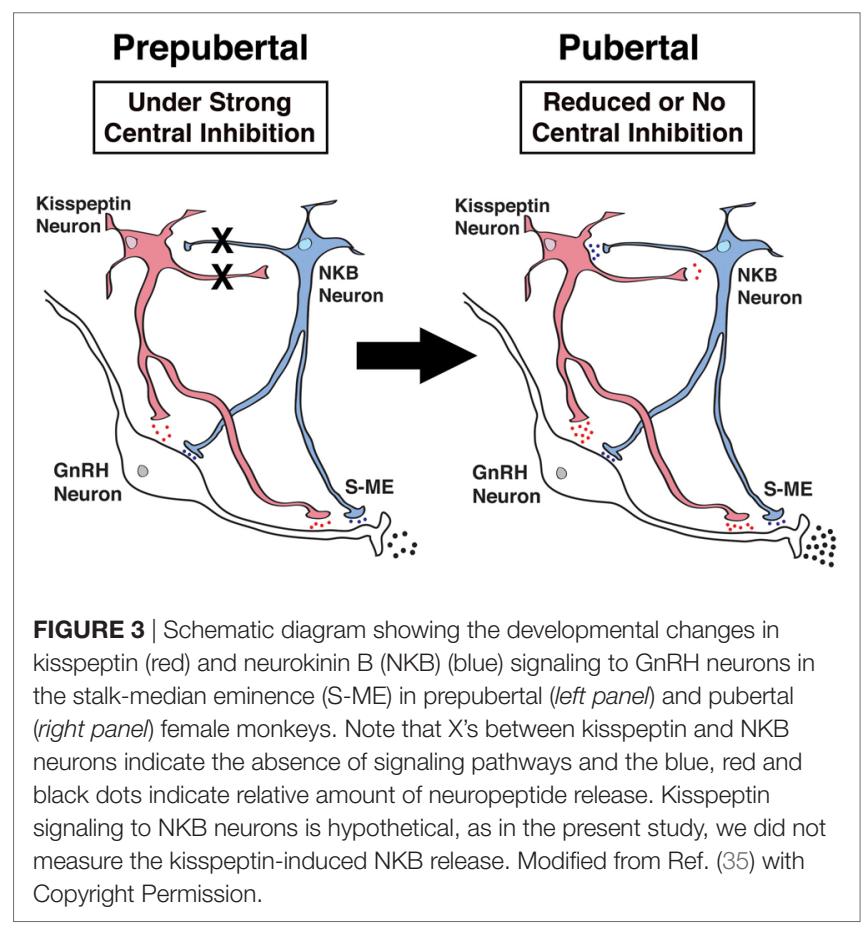


lowest by P30, just prior to vaginal opening (82), and overexpression of human GATAD1 gene by transfection in the mouse ARC results in delayed puberty, as postulated in prepubertal monkeys (83). Collectively, it appears that "Central Inhibition" is present in the rodent brain, but its functional significance may differ from that in primates.

\section{CONCLUSION}

We have shown that both kisspeptin signaling and NKB signaling appear to contribute to the pubertal increase in $\mathrm{GnRH}$ release independently or in concert in females. That is, while there is no interaction between kisspeptin and NKB signaling in sexually immature females, increases in kisspeptin signaling through NKB neurons and NKB signaling through kisspeptin neurons both augment the pubertal increase in $\mathrm{GnRH}$ release during the progress of puberty. The contribution of direct NKB signaling to GnRH release, however, may be secondary, as NKB signaling to $\mathrm{GnRH}$ release does not change across puberty, whereas NKB signaling to kisspeptin release greatly increases (Figure 2). Thus, in females, kisspeptin signaling appears to be the main force driving the pubertal $\mathrm{GnRH}$ release increases with their signaling intensity and an increased sensitivity of the receptor, KISS1R [(17, 34); Figure 2]. The role of NKB in the pubertal increase in $\mathrm{GnRH}$ release, however, requires further experiments, measuring developmental changes in

\section{REFERENCES}

1. Terasawa E, Fernandez DL. Neurobiological mechanisms of the onset of puberty in primates. Endocr Rev (2001) 22:111-51. doi:10.1210/er.22.1.111

2. Seminara SB, Messager S, Chatzidaki EE, Thresher RR, Acierno JS Jr, Shagoury JK, et al. The GPR54 gene as a regulator of puberty. N Engl J Med (2003) 349:1614-27. doi:10.1056/NEJMoa035322

3. de Roux N, Genin E, Carel J-C, Matsuda F, Chaussain J-L, Milgrom E. Hypogonadotropic hypogonadism due to loss of function of the KiSS1derived peptide receptor GPR54. Proc Natl Acad Sci U S A (2003) 100:10972-6. doi:10.1073/pnas.1834399100

4. Topaloglu AK, Reimann F, Guclu M, Yalin AS, Kotan LD, Porter KM, et al. TAC3 and TACR3 mutations in familial hypogonadotropic hypogonadism reveal a key role for neurokinin B in the central control of reproduction. Nat Genet (2009) 41:354-8. doi:10.1038/ng.306

5. Terasawa E, Nass TE, Yeoman RR, Loose MD, Schultz NJ. Hypothalamic control of puberty in the female rhesus macaque. In: Norman RL, editor. Neuroendocrine Aspects of Reproduction. New York: Academic Press (1983). p. $149-82$.

6. Wildt L, Marshall G, Knobil E. Experimental induction of puberty in the infantile rhesus monkey. Science (1980) 207:1373-5. doi:10.1126/science. 6986658

7. Watanabe G, Terasawa E. In vivo release of luteinizing hormone releasing hormone increases with puberty in the female rhesus monkey. Endocrinology (1989) 125:92-9. doi:10.1210/endo-125-1-92

8. Chongthammakun S, Claypool LE, Terasawa E. Ovariectomy increases in vivo luteinizing hormone-releasing hormone release in pubertal, but not prepubertal, female rhesus monkeys. J Neuroendocrinol (1993) 5:41-50. doi:10.1111/j.1365-2826.1993.tb00362.x

9. Sisk CL, Richardson HN, Chappell PE, Levine JE. In vivo gonadotropinreleasing hormone secretion in female rats during peripubertal development and on proestrus. Endocrinology (2001) 142:2929-36. doi:10.1210/endo.142. 7.8239

10. Harris GC, Levine JE. Pubertal acceleration of pulsatile gonadotropin-releasing hormone release in male rats as revealed by microdialysis. Endocrinology (2003) 144:163-71. doi:10.1210/en.2002-220767
NKB release in the presence or absence of kisspeptin agonists/ antagonists.

We speculate that, in females, reciprocal signaling pathways between kisspeptin and NKB neurons would provide efficiency and flexibility for the stimulation of GnRH release, which ensures complex reproductive functions, such as cyclic ovulations and pregnancy. In summary, kisspeptin signaling and NKB signaling are both indispensable to facilitate the pubertal increase in $\mathrm{GnRH}$ after removal or diminution of "Central Inhibition." Further studies, such as measurements of NKB release in the hypothalamus and examination of the role of dynorphin would strengthen our views.

\section{AUTHOR CONTRIBUTIONS}

ET and JPG designed experiments. JPG and KLK conducted experiments. JPG analyzed the data, and ET, JPG, and SBS wrote the manuscript.

\section{FUNDING}

Supported by NIH grants: R01HD011355 to ET, R01HD043341 and R01HD043341S1 to SBS, and R25GM083252 and T32HD041921 to JPG. SBS was also supported by P50 HD028138 and as a Robert and Laura Reynolds MGH Research Scholar. The work was made possible by support (OD011106) for the Wisconsin National Primate Research Center.

11. Foster DL. Puberty in the sheep. 2nd ed. In: Knobil E, Neill JD, editors. The Physiology of Reproduction. New York: Raven Press (1994). p. 411-51.

12. Penny R, Olambiwonnu NO, Frasier SD. Episodic fluctuations of serum gonadotropins in pre- and post-pubertal girls and boys. JClin Endocrinol Metab (1977) 45:307-11. doi:10.1210/jcem-45-2-307

13. Wu FC, Butler GE, Kelnar CJ, Stirling HF, Huhtaniemi I. Patterns of pulsatile luteinizing hormone and follicle-stimulating hormone secretion in prepubertal (midchildhood) boys and girls and patients with idiopathic hypogonadotropic hypogonadism (Kallmann's syndrome): a study using an ultrasensitive time-resolved immunofluorometric assay. JClin Endocrinol Metab (1991) 72:1229-37.

14. Oerter KE, Uriarte MM, Rose SR, Barnes KM, Cutler GB Jr. Gonadotropin secretory dynamics during puberty in normal girls and boys. J Clin Endocrinol Metab (1990) 71:1251-8. doi:10.1210/jcem-71-5-1251

15. Ross JL, Loriaux DL, Cutler GB Jr. Developmental changes in neuroendocrine regulation of gonadotropin secretion in gonadal dysgenesis. J Clin Endocrinol Metab (1983) 57:288-93. doi:10.1210/jcem-57-2-288

16. Keen KL, Wegner FH, Bloom SR, Ghatei MA, Terasawa E. An increase in kisspeptin-54 release occurs with the pubertal increase in luteinizing hormone-releasing hormone-1 release in the stalk-median eminence of female rhesus monkeys in vivo. Endocrinology (2008) 149:4151-7. doi:10.1210/en. 2008-0231

17. Guerriero KA, Keen KL, Terasawa E. Developmental increase in kisspeptin-54 release in vivo is independent of the pubertal increase in estradiol in female rhesus monkeys (Macaca mulatta). Endocrinology (2012) 153:1887-97. doi:10.1210/en.2011-1701

18. Chongthammakun S, Terasawa E. Negative feedback effects of estrogen on luteinizing hormone-releasing hormone release occur in pubertal, but not prepubertal, ovariectomized female rhesus monkeys. Endocrinology (1993) 132:735-43. doi:10.1210/endo.132.2.8425492

19. de Vries L, Shtaif B, Phillip M, Gat-Yablonski G. Kisspeptin serum levels in girls with central precocious puberty. Clin Endocrinol (Oxf) (2009) 71:524-8. doi:10.1111/j.1365-2265.2009.03575.x

20. Rhie YJ, Lee KH, Eun SH, Choi BM, Chae HW, Kwon AR, et al. Serum kisspeptin levels in Korean girls with central precocious puberty. J Korean Med Sci (2011) 26:927-1031. doi:10.3346/jkms.2011.26.7.927 
21. Pita J, Barrios V, Gavela-Pérez T, Martos-Moreno GÁ, Muñoz-Calvo MT, Pozo J, et al. Circulating kisspeptin levels exhibit sexual dimorphism in adults, are increased in obese prepubertal girls and do not suffer modifications in girls with idiopathic central precocious puberty. Peptides (2011) 32:1781-6. doi:10.1016/j.peptides.2011.07.016

22. Akinci A, Cetin D, Ilhan N. Plasma kisspeptin levels in girls with premature thelarche. J Clin Res Pediatr Endocrinol (2012) 4:61-5. doi:10.4274/jcrpe.615

23. Abacı A, Çatlı G, Anık A, Küme T, Çalan ÖG, Dündar BN, et al. Significance of serum neurokinin B and kisspeptin levels in the differential diagnosis of premature thelarche and idiopathic central precocious puberty. Peptides (2015) 64:29-33. doi:10.1016/j.peptides.2014.12.011

24. Muir AI, Chamberlain L, Elshourbagy NA, Michalovich D, Moore DJ, Calamari A, et al. AXOR12, a novel human G protein-coupled receptor, activated by the peptide KiSS-1. J Biol Chem (2001) 276:28969-75. doi:10.1074/ jbc.M102743200

25. Ohtaki T, Shintani Y, Honda S, Matsumoto H, Hori A, Kanehashi K, et al. Metastasis suppressor gene KiSS-1 encodes peptide ligand of a G-proteincoupled receptor. Nature (2001) 411:613-7. doi:10.1038/35079135

26. Shoji I, Hirose T, Mori N, Hiraishi K, Kato I, Shibasaki A, et al. Expression of kisspeptins and kisspeptin receptor in the kidney of chronic renal failure rats. Peptides (2010) 10:1920-5. doi:10.1016/j.peptides.2010.07.001

27. Castellano JM, Gaytan M, Roa J, Vigo E, Navarro VM, Bellido C, et al. Expression of KiSS-1 in rat ovary: putative local regulator of ovulation? Endocrinology (2006) 147:4852-62. doi:10.1210/en.2006-0117

28. Salehi S, Adeshina I, Chen H, Zirkin BR, Hussain MA, Wondisford F, et al. Developmental and endocrine regulation of kisspeptin expression in mouse Leydig cells. Endocrinology (2015) 156:1514-22. doi:10.1210/en. 2014-1606

29. Roseweir AK, Kauffman AS, Smith JT, Guerriero KA, Morgan K, PieleckaFortuna J, et al. Discovery of potent kisspeptin antagonists delineate physiological mechanisms of gonadotropin regulation. J Neurosci (2009) 29:3920-9. doi:10.1523/JNEUROSCI.5740-08.2009

30. Han SK, Gottsch ML, Lee KJ, Popa SM, Smith JT, Jakawich SK, et al. Activation of gonadotropin-releasing hormone neurons by kisspeptin as a neuroendocrine switch for the onset of puberty. JNeurosci (2005) 25:11349-56. doi:10.1523/JNEUROSCI.3328-05.2005

31. Irwig MS, Fraley GS, Smith JT, Acohido BV, Popa SM, Cunningham MJ, et al. Kisspeptin activation of gonadotropin releasing hormone neurons and regulation of KiSS-1 mRNA in the male rat. Neuroendocrinology (2004) 80:264-72. doi:10.1159/000083140

32. Ramaswamy S, Guerriero KA, Gibbs RB, Plant TM. Structural interactions between kisspeptin and GnRH neurons in the mediobasal hypothalamus of the male rhesus monkey (Macaca mulatta) as revealed by double immunofluorescence and confocal microscopy. Endocrinology (2008) 149:4387-95. doi:10.1210/en.2008-0438

33. Hrabovszky E, Ciofi P, Vida B, Horvath MC, Keller E, Caraty A, et al. The kisspeptin system of the human hypothalamus: sexual dimorphism and relationship with gonadotropin-releasing hormone and neurokinin B neurons. Eur J Neurosci (2010) 31:1984-98. doi:10.1111/j.1460-9568.2010.07239.x

34. Guerriero KA, Keen KL, Millar RP, Terasawa E. Developmental changes in GnRH release in response to kisspeptin agonist and antagonist in female rhesus monkeys (Macaca mulatta): implication for the mechanism of puberty. Endocrinology (2012) 153:825-36. doi:10.1210/en.2011-1565

35. Garcia JP, Guerriero KA, Keen KL, Kenealy BP, Seminara SB, Terasawa E. Kisspeptin and neurokinin B signaling network underlies the pubertal increase in GnRH release in female rhesus monkeys. Endocrinology (2017) 158:3269-80. doi:10.1210/en.2017-00500

36. Ruka KA, Burger LL, Moenter SM. Regulation of arcuate neurons coexpressing kisspeptin, neurokinin $\mathrm{B}$, and dynorphin by modulators of neurokinin 3 and $\mathrm{\kappa}$-opioid receptors in adult male mice. Endocrinology (2013) 154:2761-71. doi:10.1210/en.2013-1268

37. Krajewski SJ, Anderson MJ, Iles-Shih L, Chen KJ, Urbanski HF, Rance NE. Morphologic evidence that neurokinin B modulates gonadotropin-releasing hormone secretion via neurokinin 3 receptors in the rat median eminence. J Comp Neurol (2005) 489:372-86. doi:10.1002/cne.20626

38. Goubillon ML, Forsdike RA, Robinson JE, Ciofi P, Caraty A, Herbison AE. Identification of neurokinin B-expressing neurons as an highly estrogenreceptive, sexually dimorphic cell group in the ovine arcuate nucleus. Endocrinology (2000) 141:4218-25. doi:10.1210/endo.141.11.7743
39. Navarro VM, Castellano JM, McConkey SM, Pineda R, Ruiz-Pino F, Pinilla L, et al. Interactions between kisspeptin and neurokinin B in the control of GnRH secretion in the female rat. Am J Physiol Endocrinol Metab (2011) 300:E202-10. doi:10.1152/ajpendo.00517.2010

40. Navarro VM, Gottsch ML, Wu M, García-Galiano D, Hobbs SJ, Bosch MA, et al. Regulation of NKB pathways and their roles in the control of Kiss1 neurons in the arcuate nucleus of the male mouse. Endocrinology (2011) 152:4265-75. doi:10.1210/en.2011-1143

41. Ahn T, Fergani C, Coolen LM, Padmanabhan V, Lehman MN. Prenatal testosterone excess decreases neurokinin 3 receptor immunoreactivity within the arcuate nucleus KNDy cell population. J Neuroendocrinol (2015) 27:100-10. doi:10.1111/jne.12244

42. Krajewski SJ, Burke MC, Anderson MJ, McMullen NT, Rance NE. Forebrain projections of arcuate neurokinin B neurons demonstrated by anterograde tract-tracing and monosodium glutamate lesions in the rat. Neuroscience (2010) 166:680-97. doi:10.1016/j.neuroscience.2009.12.053

43. Hrabovszky E, Sipos MT, Molnár CS, Ciofi P, Borsay BÁ, Gergely P, et al. Low degree of overlap between kisspeptin, neurokinin B, and dynorphin immunoreactivities in the infundibular nucleus of young male human subjects challenges the KNDy neuron concept. Endocrinology (2012) 153:4978-89. doi:10.1210/en.2012-1545

44. Ramaswamy S, Seminara SB, Plant TM. Evidence from the agonadal juvenile male rhesus monkey (Macaca mulatta) for the view that the action of neurokinin B to trigger gonadotropin-releasing hormone release is upstream from the kisspeptin receptor. Neuroendocrinology (2011) 94:237-45. doi:10.1159/ 000329045

45. Sandoval-Guzmán T, Rance NE. Central injection of senktide, an NK3 receptor agonist, or neuropeptide $\mathrm{Y}$ inhibits $\mathrm{LH}$ secretion and induces different patterns of Fos expression in the rat hypothalamus. Brain Res (2004) 1026:307-12. doi:10.1016/j.brainres.2004.08.026

46. Ruiz-PinoF,NavarroVM,Bentsen AH,Garcia-GalianoD,Sanchez-GarridoMA, Ciofi P, et al. Neurokinin B and the control of the gonadotropic axis in the rat: developmental changes, sexual dimorphism, and regulation by gonadal steroids. Endocrinology (2012) 153:4818-29. doi:10.1210/en.2012-1287

47. Kinsey-Jones JS, Grachev P, Li XF, Lin YS, Milligan SR, Lightman SL, et al. The inhibitory effects of neurokinin B on GnRH pulse generator frequency in the female rat. Endocrinology (2012) 153:307-15. doi:10.1210/en.2011-1641

48. Goodman RL, Lehman MN, Smith JT, Coolen LM, de Oliveira CV, Jafarzadehshirazi MR, et al. Kisspeptin neurons in the arcuate nucleus of the ewe express both dynorphin A and neurokinin B. Endocrinology (2007) 148:5752-60. doi:10.1210/en.2007-0961

49. Nestor CC, Briscoe AM, Davis SM, Valent M, Goodman RL, Hileman SM. Evidence of a role for kisspeptin and neurokinin B in puberty of female sheep. Endocrinology (2012) 153:2756-65. doi:10.1210/en.2011-2009

50. Goodman RL, Coolen LM, Lehman MN. A role for neurokinin B in pulsatile GnRH secretion in the ewe. Neuroendocrinology (2014) 99:18-32. doi:10.1159/000355285

51. Navarro VM, Gottsch ML, Chavkin C, Okamura H, Clifton DK, Steiner RA. Regulation of gonadotropin-releasing hormone secretion by kisspeptin/ dynorphin/neurokinin B neurons in the arcuate nucleus of the mouse. J Neurosci (2009) 29:11859-66. doi:10.1523/JNEUROSCI.1569-09.2009

52. Wakabayashi Y, Nakada T, Murata K, Ohkura S, Mogi K, Navarro VM, et al. Neurokinin B and dynorphin A in kisspeptin neurons of the arcuate nucleus participate in generation of periodic oscillation of neural activity driving pulsatile gonadotropin-releasing hormone secretion in the goat. J Neurosci (2010) 30:3124-32. doi:10.1523/JNEUROSCI.5848-09.2010

53. Grachev P, Li XF, Kinsey-Jones JS, di Domenico AL, Millar RP, Lightman SL, et al. Suppression of the GnRH pulse generator by neurokinin B involves a K-opioid receptor-dependent mechanism. Endocrinology (2012) 153:4894904. doi:10.1210/en.2012-1574

54. Okamura H, Tsukamura H, Ohkura S, Uenoyama Y, Wakabayashi Y, Maeda K. Kisspeptin and GnRH pulse generation. Adv Exp Med Biol (2013) 784:297-323. doi:10.1007/978-1-4614-6199-9_14

55. Skrapits K, Borsay BÁ, Herczeg L, Ciofi P, Liposits Z, Hrabovszky E. Neuropeptide co-expression in hypothalamic kisspeptin neurons of laboratory animals and the human. Front Neurosci (2015) 9:29. doi:10.3389/ fnins.2015.00029

56. Ramaswamy S, Seminara SB, Ali B, Ciofi P, Amin NA, Plant TM. Neurokinin B stimulates GnRH release in the male monkey (Macaca mulatta) and is 
colocalized with kisspeptin in the arcuate nucleus. Endocrinology (2010) 151:4494-503. doi:10.1210/en.2010-0223

57. Oakley AE, Clifton DK, Steiner RA. Kisspeptin signaling in the brain. Endocr $\operatorname{Rev}(2009)$ 30:713-43. doi:10.1210/er.2009-0005

58. Clarkson J, d'Anglemont de Tassigny X, Colledge WH, Caraty A, Herbison AE. Distribution of kisspeptin neurones in the adult female mouse brain. J Neuroendocrinol (2009) 21:673-82. doi:10.1111/j.1365-2826.2009.01892.x

59. Fraioli F, Cappa M, Fabbri A, Gnessi L, Moretti C, Borrelli P, et al. Lack of endogenous opioid inhibitory tone on LH secretion in early puberty. Clin Endocrinol (1984) 20:299-305. doi:10.1111/j.1365-2265.1984.tb00086.x

60. Sauder SE, Case GD, Hopwood NJ, Kelch RP, Marshall JC. The effects of opiate antagonism on gonadotropin secretion in children and in women with hypothalamic amenorrhea. Pediatr Res (1984) 18:322-8. doi:10.1203/00006450198404000-00004

61. Mauras N, Veldhuis JD, Rogol AD. Role of endogenous opiates in pubertal maturation: opposing actions of naltrexone in prepubertal and late pubertal boys. J Clin Endocrinol Metab (1986) 62:1256-63. doi:10.1210/jcem-62-6-1256

62. Ulloa-Aguirre A, Mendez JP, Gonzalez-Castillo A, Carranza-Lira S, GarzaFlores J, Peres-Palacios G. Changes in the responsiveness of luteinizing hormone secretion to infusion of the opioid antagonist naloxone throughout male sexual maturation. Clin Endocrinol (1988) 29:17-28. doi:10.1111/j.13652265.1988.tb00245.x

63. Medhamurthy R, Gay VL, Plant TM. The prepubertal hiatus in gonadotropin secretion in the male rhesus monkey (Macaca mulatta) does not appear to involve endogenous opioid peptide restraint of hypothalamic gonadotropin-releasing hormone release. Endocrinology (1990) 126:1036-42. doi:10.1210/endo-126-2-1036

64. Blank MS, Murphy JR. Luteinizing hormone sensitivity to naloxone in maturing male chimpanzees. Brain Res Bull (1991) 27:241-5. doi:10.1016/03619230(91)90075-U

65. Ropert JF, Quigley ME, Yen SSC. Endogenous opiates modulate pulsatile luteinizing hormone release in humans. JClin Endocrinol Metab (1981) 52:583-5. doi:10.1210/jcem-52-3-583

66. Veldhius JD, Rogol AD, Samojlik E, Ertel NH. Role of endogenous opiates in the expression of negative feedback action of androgens and estrogens on pulsatile properties of luteinizing hormone secretion in man. J Clin Invest (1984) 74:47-55. doi:10.1172/JCI111417

67. Van Vugt DA, Lam NY, Fenn M. Reduced frequency of pulsatile luteinizing hormone secretion in the luteal phase of the rhesus monkey. Involvement of endogenous opiates. Endocrinology (1984) 115:1095-101. doi:10.1210/ endo-115-3-1095

68. Kesner JS, Kaufman JM, Wilson RC, Kuroda G, Knobil E. On the short-loop feedback regulation of the hypothalamic luteinizing hormone releasing hormone 'pulse generator' in the rhesus monkey. Neuroendocrinology (1986) 42:109-11. doi:10.1159/000124259

69. Vician L, Adams LA, Clifton DK, Steiner RA. Pubertal changes in proopiomelanocortin and gonadotropin releasing hormone gene expression in the brain of the male monkey. Mol Cell Neurosci (1991) 2:31-8. doi:10.1016/1044-7431(91)90037-O

70. Terasawa E, Chongthammakun S. Developmental changes in in vivo release of $\beta$-endorphin ( $\beta$-END) from the stalk-median eminence (S-ME) in female rhesus monkeys. Proceedings of the 21st Annual Meeting of the Neuroscience Society Held November 10-15. (Vol. 17), New Orleans, LA: Society for Neuroscience (1991). 906 p. (Abstract No. 361.1).

71. Ebling FJ, Schwartz ML, Foster DL. Endogenous opioid regulation of pulsatile luteinizing hormone secretion during sexual maturation in the female sheep. Endocrinology (1989) 125:369-83. doi:10.1210/endo-125-1-369

72. Kenealy BP, Keen KL, Kapoor A, Terasawa E. Neuroestradiol in the stalk median eminence of female rhesus macaques decreases in association with puberty onset. Endocrinology (2016) 157:70-6. doi:10.1210/en.2015-1770

73. Anthony ELP, King JC, Stopa EG. Immunocytochemical localization of LHRH in the median eminence, infundibular stalk, and neurohypophysis: evidence for multiple sites of releasing hormone secretion in humans and other mammals. Cell Tissue Res (1984) 236:5-14. doi:10.1007/BF00216506
74. Silverman AJ, Antunes JL, Ferin M, Zimmerman EA. The distribution of luteinizing hormone-releasing hormone in the hypothalamus of the rhesus monkey. Endocrinology (1977) 101:134-42. doi:10.1210/endo-101-1-134

75. Colledge WH, Doran J, Mei H. Model systems for studying kisspeptin signalling: mice and cells. Adv Exp Med Biol (2013) 784:481-503. doi:10.1007/ 978-1-4614-6199-9_22

76. True C, Nasrin Alam S, Cox K, Chan YM, Seminara SB. Neurokinin B is critical for normal timing of sexual maturation but dispensable for adult reproductive function in female mice. Endocrinology (2015) 156:1386-97. doi:10.1210/en.2014-1862

77. Han SY, McLennan T, Czieselsky K, Herbison AE. Selective optogenetic activation of arcuate kisspeptin neurons generates pulsatile luteinizing hormone secretion. Proc Natl Acad Sci U S A (2015) 112:13109-14. doi:10.1073/ pnas. 1512243112

78. Kelly MJ, Zhang C, Qiu J, Rønnekleiv OK. Pacemaking kisspeptin neurons. Exp Physiol (2013) 98:1535-43. doi:10.1113/expphysiol.2013.074559

79. Plant TM. Puberty in primates. In: Knobil E, Neill JD, editors. The Physiology of Reproduction. New York: Raven (1988). p. 1763-88.

80. Terasawa E, Guerriero KA, Plant TM. Kisspeptin and puberty in mammals. Adv Exp Med Biol (2013) 784:253-73. doi:10.1007/978-1-4614-6199-9_12

81. Terasawa E. Postnatal development of GnRH neuronal function. In: Plant TM, Herbison AE, editors. International Neuroendocrine Federation Masterclass Series: The GnRH Neuron and its Control. New York: Wiley-Blackwell (2018). p. 61-91.

82. Abreu AP, Dauber A, Macedo DB, Noel SD, Brito VN, Gill JC, et al. Central precocious puberty caused by mutations in the imprinted gene MKRN3. $N$ Engl J Med (2013) 368:2467-75. doi:10.1056/NEJMoa1302160

83. Lomniczi A, Wright H, Castellano JM, Matagne V, Toro CA, Ramaswamy S, et al. Epigenetic regulation of puberty via zinc finger protein-mediated transcriptional repression. Nat Comm (2015) 6:10195. doi:10.1038/ncomms10195

84. Kurian JR, Keen KL, Guerriero KA, Terasawa E. Tonic control of kisspeptin release in prepubertal monkeys: implications to the mechanism of puberty onset. Endocrinology (2012) 153:3331-6. doi:10.1210/en.2012-1221

85. Grumbach MM. The neuroendocrinology of human puberty revisited. Horm Res (2002) 57(Suppl 2):2-14. doi:10.1159/000058094

86. Plant TM, Barker-Gibb ML. Neurobiological mechanisms of puberty in higher primates. Hum Reprod Update (2004) 10:67-77. doi:10.1093/humupd/ dmh001

87. Pohl CR, deRidder CM, Plant TM. Gonadal and nongonadal mechanisms contribute to the prepubertal hiatus in gonadotropin secretion in the female rhesus monkey (Macaca mulatta). JClin Endocrinol Metab (1995) 80:2094-101. doi:10.1210/jc.80.7.2094

88. Ojeda SR, Urbanski HF. Puberty in the Rat. In: Knobil E, Neill JD, editors. The Physiology of Reproduction, New York, NY: Raven (1994). p. 363-409.

89. Plant TM, Gay VL, Marshall GR, Arslan M. Puberty in monkeys is triggered by chemical stimulation of the hypothalamus. Proc Natl Acad Sci USA (1989) 86:2506-10.

90. Smyth C, Wilkinson M. A critical period for glutamate receptor-mediated induction of precocious puberty in female rats. J Neuroendocrinol (1994) 6:275-84.

Conflict of Interest Statement: The authors declare that the research was conducted in the absence of any commercial or financial relationships that could be construed as a potential conflict of interest.

The reviewer VN declared a shared affiliation, with no collaboration, with one of the authors, SBS, to the handling Editor.

Copyright (® 2018 Terasawa, Garcia, Seminara and Keen. This is an open-access article distributed under the terms of the Creative Commons Attribution License (CC BY). The use, distribution or reproduction in other forums is permitted, provided the original author(s) and the copyright owner are credited and that the original publication in this journal is cited, in accordance with accepted academic practice. No use, distribution or reproduction is permitted which does not comply with these terms. 